\title{
Opening the Black-box of Bank Efficiency in Turkey with Two-stage Data Envelopment Analysis: A Study on Capital Adequacy Ratio
}

\author{
Emine Ebru AKIN AKSOY ${ }^{1} \odot$, Ceren DiRiK ${ }^{2} \odot$, İlkut Elif KANDIL GÖKER ${ }^{3} \odot$
}

\begin{abstract}
Banks constitute approximately $90 \%$ of the Turkish financial system, so an efficiently operating banking sector is essential for financial consolidation. To ensure the efficient functioning of the banking production process, capital adequacy ratio (CAR), which is a basic indicator in controlling financial risk, should be managed properly. Additionally, the production process of banks fits into a typical two-stage system, thus opening the black-box on bank efficiency is necessary for an accurate efficiency measurement. By focusing on the link between efficiency, risk and return, this study aims to present a two-stage efficiency evaluation of the commercial banks in Turkey for the year 2018. In addition to the efficiency scores, frontier projections are determined, and an examination is made on the CAR targets. The empirical findings indicate that the inefficiency in the Turkish banking sector mainly stems from the operational performance and the average efficiency score of the state-owned banks is the highest. According to the target values, a pattern is detected between the efficiency scores and CAR. We also conclude that the minimum capital adequacy of $10.5 \%$ set by Basel III is not high to guide the commercial banks in Turkey to the efficient frontier.
\end{abstract}

Keywords: Two-stage Data Envelopment Analysis, Capital Adequacy Ratio, Bank Efficiency.

JEL Codes: C44, C61, G21, G28.

\section{INTRODUCTION}

With globalization and internationalization, direct trade flows and capital flows have accelerated, and consequently national markets have linked to one another. Therefore, cross-border market connections have emerged, and the potential risk transmitted internationally has increased. Briefly stated, in the current era, economic developments taking place anywhere in the world have direct or indirect effects on other countries. This situation creates a notable risk impact on the banking sector, which is the main part of the financial sector of many countries. In fact, from an economic point of view, any event that may adversely affect the financial sector that finances the real sector directly affects the real sector as well. On the other hand, many countries' financial sectors have also entered into international transactions, leading to a higher level of operational risk. For this reason, the financial sector needs to be protected from various risks, and the maintenance of financial stability is an essential task of financial authorities. At this point, it is a known fact that the robustness of the financial sector depends particularly on banks' asset quality, liquidity risk, capital adequacy and financial performance.

In 2008, a global financial crisis that was originated from the collapse of the mortgage market occurred in the United States. Especially, subprime borrowers' defaults brought the crisis in the mortgage market. The most important consequence of this crisis was the contagion effect from the United States to cross-border countries. Moreover, many financial institutions and banks went bankrupt due to having a large extent of mortgage-backed securities within their portfolios. These results showed the financial restructuring

\footnotetext{
emine.aksoy@hbv.edu.tr

2 cerendirik@kku.edu.tr

3 elifkandil@kku.edu.tr
} 
requirement of banks and financial institutions. In this context, it has been concluded that capital adequacy, which is the ratio of a bank's core capital to the assets and off-balanced liabilities weighted by the risk (Bialas and Solek, 2010), should be revised. Since one of the main measures of a bank's ability to overcome financial loss is capital adequacy ratio (CAR) (Posner, 2015), a regulation is needed on what percentage this ratio should be at least.

The G-10 countries, Spain and Luxembourg established the Basel Committee in 1974 under the control of the world's oldest financial organization, Bank for International Settlements. The Basel Committee on Banking Supervision (BCBS) issued a set of minimum capital requirements called Basel I in 1988. With Basel I, banks were advised that the ratio of equity to risk-weighted assets should not be less than $8 \%$. Subsequently, under Basel II, which entered into force in 2004, the minimum CAR was left unchanged at $8 \%$ but operational risk was included in the calculation of the minimum capital requirements on top of credit and market risk. However, because of the 2008 crisis, Basel II implementation was considered to have some shortcomings, so Basel III norms were proposed in 2010 and the minimum CAR was increased to $10.5 \%$. As Gual (2011) states, the main objectives of Basel III are to guarantee that banks possess higher levels of equity to overcome potential losses and also to ensure that banks stay on lower levels of risk. Basel III was planned to be introduced from 2013 until 2015, but changes from 2013 extended implementation until 2019. Taken as a whole, all these regulations aim to protect banks against risks that may arise both inside and outside by increasing their capital.

As CAR increases, the amount of equity increases and the amount of risk decreases. Hence, a higher level of capital serves as a safeguard that reduces the probability of bank failure, an incentive force for better risk management and an indicator of maintaining long-term customer relationships. Furthermore, banks with strong CARs can attract funds and find additional sources easily. However, capital does not only provide several benefits but also creates certain costs from the viewpoint of financial stability. When a bank replaces its debts with equity, the surplus of the bank's profit decreases for cash investors, so the cost of credit increases for the bank. Moreover, a higher level of capital brings along additional costs specific to the banking system (Dagher et al., 2016). For example, if a bank has a high CAR, it can easily bear a project that involves risk, but may endure high operating cost at the same time (Besanko and Kanatas, 1996). In addition to all these, there is a conflict due to the inconsistency of the goals of "monetary policymakers", who work to assure sufficient lending activities for stable economic growth, and "banks' financial supervisors", who control banks' lending capacity to prevent them from excessive risk. To reconcile both sides, an interest rate strategy that considers the capital adequacy requirement can be approved (Cecchetti and Li, 2008). In brief, determining neither more nor less CAR that increases profitability and decreases risk is vital for banks.

In Turkey, the banks play the most important role in financing the economy. Turkey suffered from two different banking crises in 1994 and 2001. As a result of these crises, many banks went bankrupt and Turkey realized the need for new regulations regarding to the banking sector. Banking Regulation and Supervision Agency of Turkey (BRSA) was founded in 1999 to constitute confidence and stability within the financial markets, to protect the savers' rights and benefits and to provide the efficient functioning of the credit mechanism. Moreover, Turkey became a member of the BCBS and Financial Stability Board in 2009. By virtue of the structural reforms and regulations undertaken over the years, the Turkish banking system has strengthened. With reference to the Turkish Banking Sector Main Indicators (BRSA, 2019), the banking sector's total asset is 4234 billion Turkish Liras in June 2019. By the end of 2018, the ratio of the banking sector's asset size to GDP is 1.04 (BRSA, 2019), and the share of the banking sector in the financial sector is $87.2 \%$ (BRSA, 2018). These data illustrate the dominance of the banking sector, so an efficiently operating banking system has an undeniable importance for the maintenance of financial stability in Turkey. To ensure that a bank's production process runs efficiently, a balance is needed between risk and return, which can be achieved with a proper level of capital adequacy. The average CARs between the years 2010-2019 for the Turkish banking sector, including all commercial, participation, development and investment banks, are 18.97, 16.55, 17.86, 15.28, 16.28, 15.57, $15.57,16.85,17.30$ and 17.73 , respectively (BRSA, 2019). According to these figures, it is clearly seen that the average CARs by years remain at fairly high levels. This suggests that the Turkish banking sector has lowered its risk by keeping CAR high. Nevertheless, the cost of capital has increased correspondingly, and an increase in the cost of capital may lead to a decrease in profit, performance and value of banks (Modigliani and Miller, 1963). In this respect, the efficiency assessment of the banks in Turkey and the effect of CAR on bank efficiency 
become an important issue in today's world where international standards are established on capital adequacy to provide the robustness of the banking system.

Data envelopment analysis (DEA) is one of the most widely used methods to measure the efficiency of the banking system both at the micro-level (i.e. branches or banks) and macro-level (i.e. countries and regions). However, approaching a complex production system consisting of multiple sub-processes as a black-box is the biggest disadvantage of the standard DEA. It is a matter of fact that the banking production process fits into a typical two-stage system (Wang et al., 2014), thus opening the black-box on bank efficiency is of great importance. The present study is therefore intended to make several contributions to the literature on the Turkish banking system's efficiency by dividing the production process into two stages and considering "CAR, investments and performing loans" as the intermediate variables. For this purpose, a two-stage DEA model is used as the methodology. Besides the evaluation of the banking sector's overall efficiency, it is determined at which stage/stages of the production process that the banks are efficient/inefficient, so an overview of the efficiency problems experienced by the Turkish banking system in 2018 is provided. Additionally, we aim to calculate the frontier projections, especially CAR targets, for each commercial bank. In this way, a perspective on the question of whether the target CAR of $10.5 \%$ set by Basel III is low or high to guide the commercial banks to the efficient frontier is presented. The analysis covers the year 2018 when some periodic financial breaks experienced in Turkey, especially in the third quarter, and the banking system went through a balancing process.

As Fukuyama and Matousek (2011) points out, findings on a bank's efficiency provide regulatory agencies with additional information about the bank's behavior, and the need for such information is more evident in emerging market economies because of the inherent fragility of the banking systems. Moreover, the efficiency evaluation of the Turkish banking sector is particularly interesting due to the structural reforms carried out after the 2001 crisis, and sector actors need to monitor and improve their performances in order to survive in an increasingly competitive environment. As far as we know, no previous studies have addressed the issue of opening the black-box on the banking production process of Turkey based on the relationship between efficiency, risk and return. Moreover, this is the first research to use a relational two-stage DEA approach in calculating CAR targets for the banks in Turkey. Having knowledge about a bank's proper level of CAR is valuable especially for policymakers and bank supervisors. Since CAR is considered as an intermediate variable rather than an initial input or a final output, the calculated target CAR will provide an equilibrium point for banks and better suit their own dynamics on the way to reducing risk and improving performance. Therefore, the findings of the study are expected to guide the banks and fill the gap in the literature.

The remainder of this paper is organized as follows: Section 2 briefly sets out the studies conducted to investigate "the determinants of CAR", "the relationship between performance, profitability, risk and CAR" and "the impact of CAR on banking efficiency". Section 3 provides a general overview of the two-stage DEA approach and gives the model used in the analysis. Section 4 presents information on the sample, data and variables. The background of the application is described in detail in this section as well. Section 5 discusses the findings. The last section ends with the main conclusion, the limitation of the study and the suggestion for future research.

\section{LITERATURE REVIEW}

In the existing literature, there are several studies aimed at presenting empirical evidence to explain the factors affecting CAR. The research of Reynolds et al. (2000) is one of these studies in which CAR is defined as a response variable. The authors investigated the financial structure of banks operating in eight East and Southeast Asian countries from 1987 to 1997. They indicated that CAR decreases with size and is also directly related to profit. In a research on the Turkish banks, Buyuksalvarci and Abdioglu (2011) studied the capital adequacy determinants and revealed that return on equity, leverage and loans have a negative effect, while return on assets and loan loss reserve have a positive effect on CAR. The determinants of CAR during 19802008 in Nigeria are examined by Williams (2011), and a negative relationship is found between CAR and inflation. Polat and Al-khalaf (2014) investigated the internal factors influencing CAR for the banks in Kingdom of Saudi Arabia. They stated that size and leverage have a positive effect, while loans to assets ratio has a negative effect in determining CAR.

Besides the above-mentioned papers that examine the factors influencing CAR, there are a large number of studies investigating whether CAR has a positive 
or negative effect on performance, profitability and risk-taking behavior of banks. In one of these studies, Mushtaq et al. (2015) aimed to search how CAR affect the performance of commercial banks in Pakistan by using regression analysis. In their model where the bank performance is tried to be measured on the basis of return on assets, it is determined that CAR has a notable positive impact on financial performance. A similar finding is obtained in the research of Tabari et al. (2013). The authors intended to analyze the factors affecting the profitability of commercial banks in Iran. As a conclusion, they asserted that CAR, bank size and assets management lead to an improvement in bank performance. Bouheni and Rachdi (2015) contributed to the literature with their research on the efficiency of regulatory capital requirements in reducing the willingness of the Tunisian commercial banks to take risk. The authors found that an increase in equity is accompanied by a decline in bank risk-taking behavior. As Dagher et al. (2016) points out, capital plays a fundamental role in decreasing the likelihood of financial failure. This is due to its ability to develop a better risk management. Moreover, many empirical studies reveal that well-capitalized banks are expected to raise their profitability (Berger, 1995). Abreu and Mendes (2002) clarify the reason of the positive relationship between capital and profitability as follows; as the capital to asset ratio of banks increases, interest margins will increase, which will increase banks' profitability in return.

Contrary to the positive effects of CAR, Bhattacharya (2013) asserted that capital regulation has significantly reduced the growth rate of the United States banks' assets over the pre-regulation period (low capital regime between 1950 and 1979), and showed that during the post-regulation period (high capital regime between 1980 and 2004), the banks' asset generation capacity has been halved while return on assets has doubled and loss on assets has raised by 2.5 times. Thus, the author concluded that the capital adequacy regulations result in a higher risk for the United States banking industry. Additionally, Cai and Huang (2014) found that the impact of CAR on return on assets is negative in the Chinese banking sector. They also investigated how non-performing loan is improved by the restriction of CAR.

Examining the impact of CAR on bank efficiency has also grabbed researchers' attention. For instance, Bhattacharyya et al. (1997) employed a DEA model to analyze the efficiency of 70 Indian banks over the period 1986 through 1991. The input variables were interest expense and operating expense, while the output variables were deposits, loans and investments. The analysis also included six exogenous variables, namely the number of rural, suburban, urban and metropolitan branches, the ratio of loans on preferential industries to total loans and CAR. The authors noted that the average efficiency of publicly-owned banks is the highest, and the foreign-owned banks achieve performance gains even though their performance is prevented by the capital adequacy requirements. Using DEA with Tobit model, Jackson and Fethi (2000) attempted to make an investigation on the efficiency of the commercial banks in Turkey and also tried to clarify the variation in efficiency scores with a group of explanatory variables, that is the size of banks, the number of branches, ownership, profitability and CAR. They found that larger and profitable banks have higher efficiency scores and that CAR has a statistically significant negative impact on banks' performance. Another study on banking efficiency belong to Grigorian and Manole (2006). The authors used DEA in conjunction with Tobit analysis and concluded that tighter CAR is correlated with a superior revenue-generating capacity and more aggressive deposit-taking behavior.

Banking has also been studied with two-stage DEA models. One of these studies was conducted by Seiford and Zhu (1999). In their paper, the production process of the top 55 United States banks was divided into profitability and marketability stages. The authors used three inputs (assets, employees and shareholders' equity) and three outputs (total return on investors, earnings per share and market value) together with two intermediate variables (revenues and profits). Fukuyama and Matousek (2011), on the other hand, employed both the standard and network DEA models to conduct a comparative analysis and to evaluate the Turkish banking system's efficiency for the period 19912007. They stated that there is a gap among the best and worst performing banks in the way of cost efficiency and that the standard approach generates higher efficiency scores compared to the network model, so the standard DEA may lead to incorrect signals. Wang et al. (2014) aimed to evaluate the efficiency of 16 Chinese commercial banks utilizing an additive type two-stage DEA model and incorporating non-performing loan as an undesirable output to the analysis. The authors highlighted the superiority of the two-stage DEA over the standard DEA approach and concluded that the inefficiency problem in the banking system of China stemmed from the deposit producing sub-process. In another study, Li et al. (2016) used a multiplicative 
type two-stage DEA model under the assumption of constant returns to scale and output-orientation. The authors divided the banking production process to measure the operationality as well as profitability of Taiwan domestic commercial banks and to calculate the optimal CAR for each bank. Working with the data of 31 banks from 2007 to 2009, they found that most banks' optimal CARs are above $8 \%$, and $11.8 \%$ of banks' optimal CARs are below the Basel III requirement. In a similar manner, we aim to investigate the two-stage efficiency of the commercial banks in Turkey. As will be explained in more detail in the following section, an input-oriented two-stage DEA model is used with the variable returns to scale technology, as opposed to the model employed by Li et al. (2016).

\section{METHOD}

$D E A$ is a linear programming-based method used to measure the relative efficiency of a set of comparable decision-making units (DMUs) with multiple inputs and outputs. The key feature of the method is that it does not require any analytical form behind the production function. The constant returns to scale (CRS) model and the variable returns to scale (VRS) model, which are known as the standard DEA models, have attracted the attention of many researchers and found widespread use in the literature. Generally speaking, it is recommended to use the CRS assumption when DMUs are known to operate at their optimal scale and full proportionality is available between input-output variables, otherwise the VRS assumption will be more appropriate for performance evaluation. In the presence of intermediate measures or sub-processes, however, the standard DEA is considered a black-box approach because the method evaluates the whole production process as a single stage. In other words, the internal structures of DMUs are not addressed. Besides, since many DMUs have network production systems in real-world settings, the application of the standard DEA for such complex systems may lead to overestimation of efficiency scores, and thus misleading findings (Kao, 2009). Much effort has recently been devoted to the network DEA approach in order to overcome this drawback, that is, to open the so-called black-box. Having knowledge about the internal structures of DMUs and identifying the factors that lead to inefficiency are crucial so that more effective performance appraisals can be made and more specific precautions can be taken.

Two-stage serial process is known as the most fundamental structure in the network DEA literature (Lim and Zhu, 2019). With the extension of the standard DEA to this two-stage approach, the overall efficiency is split into its components, and the intermediate measures defined as both the outputs of the first stage and the inputs of the second stage are taken into consideration. Therefore, in addition to the overall/two-stage efficiency score, the efficiency score of each sub-process can also be obtained.

To the best of our knowledge, Wang et al. (1997) and Seiford and Zhu (1999) are the first researches who studied the two-stage structures to measure efficiency with DEA. Wang et al. (1997) examine the efficiency of 22 banks by dividing the banking production process into the stages of collection of funds and investment, while Seiford and Zhu (1999) analyze the profitability and marketability of the top 55 US commercial banks. In these initial studies, although the efficiency decomposition is evaluated subject to a two-stage structure, the sub-processes are assumed to be independent of each other. The other applications of the independent approach include those of Zhu (2000) on Fortune 500 companies, Sexton and Lewis (2003) on baseball teams and $\mathrm{Ho}$ and $\mathrm{Oh}$ (2008) on online stockbrokers. However, this state of independence causes not only to the neglect of possible conflicts among the stages due to the intermediate measures but also to the failure to reflect the relationship between the stages and the entire production system (Kao and Hwang, 2008). Contrary to the independent two-stage DEA models, Liang et al. (2008), Kao and Hwang (2008, 2011), Chen et al. (2009) and Chen et al. (2010) developed relational models. The assumption that the first and second stages are dependent on each other provides more reliable and detailed information for efficiency evaluation (Wang et al., 2014). In the literature, there are other variations of the above-mentioned studies on the two-stage structure in question, depending on the envelopment/ multiplier form, CRS/VRS assumption, multiplicative/ additive type of decomposition etc.

In the current study, we concentrate on the basic two-stage serial process. In this layout, the outputs from the first stage become the only inputs to the second stage. Our aim is not only to measure the overall efficiency and stage efficiencies of the commercial banks in Turkey but also to calculate the frontier projection, especially CAR target, for each inefficient DMU. Considering the fact that the DMUs we address herein have more flexibility and control over their input variables rather than the outputs, it is preferred to use an input-oriented model that aims to decrease inputs while keeping outputs constant. Moreover, the efficiency analysis is carried out under the VRS assumption, 
taking into account that the observed banks differ in size, the full proportionality is not available between the variables, and the other reasons - i.e. imperfect market competition and financial constraints. For the very reason, all mathematical formulations in the rest of this section are given by the "input-orientation" and "VRS technology".

$$
D M U_{j}, j=1,2, \ldots, n
$$

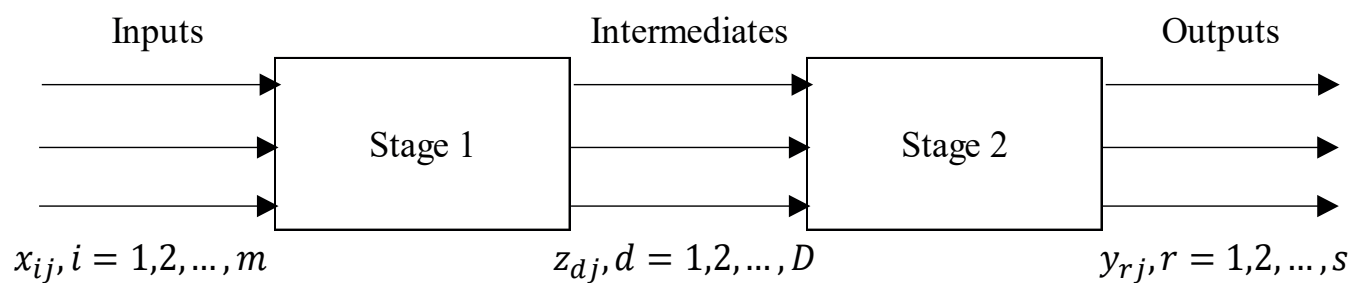

Source: Chen et al. (2010)

Figure 1: Two-stage Serial Process

Consider a two-stage serial process given in Figure 1. For $n$ DMUs $(j=1,2, \ldots, n)$ there are also intermediate measures $z_{d j}(d=1, \ldots, D)$ in addition to the inputs $x_{i j}(i=1,2, \ldots, m)$ and outputs $y_{r j}(r=1,2, \ldots, s)$ . It should be noted that the assumption of Kao and Hwang (2008) for intermediates is also made for the problem we deal with in this paper. This assumption requires that the aggregated value of intermediate measures does not change between the stages. Thus, the multiplicative type overall efficiency score under the VRS assumption can be obtained using model (1) where $D M U_{o}$ represents the particular DMU being evaluated (Lim and Zhu, 2019).

$\max \sum_{r=1}^{s} u_{r} y_{r o}+\xi_{1}+\xi_{2}$

subject to

$$
\begin{array}{ll}
\sum_{d=1}^{D} w_{d} z_{d j}+\xi_{1} \leq \sum_{i=1}^{m} v_{i} x_{i j} & \forall j=1,2, \ldots, n \\
\sum_{r=1}^{s} u_{r} y_{r j}+\xi_{2} \leq \sum_{d=1}^{D} w_{d} z_{d j} & \forall j=1,2, \ldots, n \\
\sum_{i=1}^{m} v_{i} x_{i o}=1 & \\
v_{i}, u_{r}, w_{d} \geq 0 & \forall i=1,2, \ldots, m \quad r=1,2, \ldots, s \\
& d=1,2, \ldots, D
\end{array}
$$

As can be seen from model (1), $v_{i}, w_{d}, u_{r}, \xi_{1}$ and $\xi_{2}$ are the decision variables. The model should be solved separately for each DMU ( $n$-times) so that the overall efficiency scores can be determined. A DMU with an overall efficiency score of 1 is regarded as a relatively efficient unit, while a DMU with an overall efficiency score of less than 1 is evaluated as a relatively inefficient unit. By using optimal $v_{i}^{*}, w_{d}^{*}, u_{r}^{*}, \xi_{1}^{*}$ and $\xi_{2}^{*}$ values, the divisional efficiency scores of $D M U_{o}$ can also be computed. According to Kao and Hwang's (2008) multiplicative approach, the overall efficiency score $\left(\theta^{*}\right)$ is equal to the product of the two sub-processes' efficiencies $\left(\theta_{1}^{*} \times \theta_{2}^{*}\right)$. Thus, the efficiency scores of the first stage and second stage for $D M U_{o}$ are determined with the formulas given in equation (2) and (3), respectively.

$$
\begin{aligned}
& \theta_{1}^{*}=\frac{\sum_{d=1}^{D} w_{d}^{*} z_{d o}+\xi_{1}^{*}}{\sum_{i=1}^{m} v_{i}^{*} x_{i o}} \\
& \theta_{2}^{*}=\frac{\sum_{r=1}^{S} u_{r}^{*} y_{r o}+\xi_{1}^{*}+\xi_{2}^{*}}{\sum_{d=1}^{D} w_{d}^{*} z_{d o}+\xi_{1}^{*}}
\end{aligned}
$$

Model (1) provides the overall efficiency score but does not give a relevant projection on how an inefficient DMU could reach the efficient frontier. Unlike the standard one-stage DEA approach, adjusting input or output values by the efficiency scores is not enough for the projection of the DEA frontier (Chen et al., 2010). An equivalent model given below, which is the envelopment form of model (1), should be used to overcome this deficiency.

$\min \theta$

subject to

$\sum_{j=1}^{n} x_{i j} \lambda_{j} \leq \theta x_{i o}$

$\forall i=1,2, \ldots, m$

$\sum_{j=1}^{n} y_{r j} \mu_{j} \geq y_{\text {ro }}$

$\forall r=1,2, \ldots, s$

$\sum_{j=1}^{n} z_{d j} \lambda_{j} \geq \sum_{j=1}^{n} z_{d j} \mu_{j}$

$\forall d=1,2, \ldots, D$

$\sum_{j=1}^{n} \lambda_{j}=\sum_{j=1}^{n} \mu_{j}=1$

$\lambda_{j} \geq 0 \quad \mu_{j} \geq 0$

$\forall j=1,2, \ldots, n$

$\theta, \lambda_{j}$ and $\mu_{j}$ are the decision variables of model (4). More clearly, $\lambda_{j}$ and $\mu_{j}$ are the intensity variables of stage I and II, respectively, while the unrestricted in sign variable $\theta$ corresponds to the two-stage overall efficiency score of $D M U_{o}$. When model (4) is solved for 
$D M U_{o}$, the optimal $\theta^{*}, \lambda_{j}^{*}$ and $\mu_{j}^{*}$ values are obtained. Then, in the input-oriented case, the frontier projection point can be calculated using the optimal solution as follows:

$$
\left(\tilde{x}_{i o}, \tilde{z}_{d o}, y_{r o}\right)=\left(\sum_{j=1}^{n} x_{i j} \lambda_{j}^{*}, \tilde{z}_{d o}, y_{r o}\right)
$$

where improvement targets of intermediates $\left(\tilde{z}_{d o}\right)$ can be any choice such that $\sum_{j=1}^{n} z_{d j} \mu_{j}^{*} \leq \tilde{z}_{d o} \leq \sum_{j=1}^{n} z_{d j} \lambda_{j}^{*}$ (Lim and Zhu, 2019). As Lim and Zhu (2016) stated, $\sum_{j=1}^{n} z_{d j} \mu_{j}^{*}$ or $\sum_{j=1}^{n} z_{d j} \lambda_{j}^{*}$ would be an easy choice for $\tilde{z}_{d o}$. In the application of this study, however, we prefer to proceed with the formula $\frac{\sum_{j=1}^{n} z_{d j} \mu_{j}^{*}+\sum_{j=1}^{n} z_{d j} \lambda_{j}^{*}}{2}$.

\section{SAMPLE, DATA AND VARIABLES}

The banking production process is better suited to the network system consisting of relational stages. For this reason, the banking production process should not be regarded as a black-box that converts the initial inputs into the final outputs. In other words, it is necessary to open the so-called black-box and consider the sub-processes in it for an accurate efficiency evaluation. In the light of this information, we aim to analyze two-stage efficiency of the commercial banks in Turkey by focusing on the operationality and profitability parts of the entire production process, determine the frontier points and dig deeper into the projection of CAR. As already mentioned, the unfavorable global and domestic developments experienced in 2018 caused the Turkish banking sector to go through a difficult period. In such a way that, the Turkish economy suffered a currency crisis in August 2018. While the USD/TL exchange rate was $1 \$=3.77 £$ in the first days of January, it increased to $1 \$=6.41$ on 31 August. According to the 2018 balance of payments statistics of the Central Bank of the Republic of Turkey, a high amount of capital outflow is observed both in portfolio investments and foreign direct investments. The decrease in foreign direct investments in March, June, October and November are 1077, 1045, 1383, 1268 million \$, respectively. In the first nine months of 2018, 3.1 billion \$ portfolio investments left the country. It took two years for GDP to reach the pre-crises values. For this reason, the year 2018 , when the financial fragility is so high, is deliberately chosen since it is aimed to determine the efficiency levels of banks in the crisis environment, to reveal their status in financial risk management and to examine how they managed and should manage CAR as a risk management tool. There are 34 commercial banks operating in Turkey in the specified year. Nevertheless, since the positivity requirement of DEA necessitates that all numbers must be non-negative and preferably strictly positive, three banks with missing or negative data are excluded from the analysis. Therefore, our study consists of the data for 31 banks: 3 of which are state-owned, 8 of which are privately-owned, 19 of which are foreign and 1 of which is under the deposit insurance fund. The dataset is collected from the Data Query System of the Banks Association of Turkey and the Banks in Turkey 2018 report (The Banks Association of Turkey, 2019).

Three different approaches are generally employed to determine the variables to be used in measuring the banking efficiency. These are intermediation, production and profitability approaches. In this study, it is aimed to make a more holistic evaluation by considering the perspectives of all approaches. Furthermore, the variables are chosen to reflect the definition of each production stage. Accordingly, the first stage is characterized by the asset management performance of banks, namely "operationality". In fact, the fundamental elements that banks use to start production are fixed assets and personnel. An increase in the fixed assets is expected to raise the productivity of banks by creating situations such as opening more branches, buying computers etc. Additionally, banks operate in the service sector, so personnel are also vital. Productivity is supposed to be raised by hiring more staff or more qualified staff. These actions eventually turn back to banks as an increase in personnel expense. Thus, by organizing assets and employees well, banks are expected to operate efficiently. From this point of view, the first stage's inputs are identified as "fixed assets" (see e.g. Nigmonov, 2010; Karray and Chichti, 2013) and "employee expenses" (see e.g. Wanke and Barros, 2014; Degl'Innocenti et al., 2017).

As the operationality of banks increases, it is projected that the main products, which are performing loans and financial investments, will also increase. Such that, banks are expected to perform their intermediary duties in the best way with the right asset management and ultimately provide more loans. Besides, banks are supposed to convert their excessive liquidity into financial asset investments. In this respect, "investments" and "performing loans" are taken as the first stage's outputs (see e.g. Sturm and Williams, 2008; Li et al., 2016). "CAR" is considered as another output of the first stage (see e.g. Li et al., 2016) because if a bank wants to increase its capital to the regulatory level, it has to raise its operational performance. With the inclusion of CAR, the number 
of outputs of the first stage is three. These three outputs are the input variables of the second stage as well.

The second stage, on the other hand, is characterized as "profitability", and the second stage's outputs are determined as "interest income" and "non-interest income" (see e.g. Wang et al., 2014; Li et al., 2016). When banks are evaluated as commercial enterprises, it is possible to say that their essential tasks are to collect deposits and use them as loans. The main output from the loans extended is interest income. This is the gain of banks in consequence of their intermediary function. Apart from the credit mechanism, banks also carry out transactions that they receive fees and commissions. The earning obtained as a result of these transactions is called non-interest income.

Figure 2 shows the two-stage DEA framework in terms of the variables selected for banking efficiency evaluation. In this regard, we can say that our dataset covers the banking system items that are well-suited to the adopted model. Because, although the variables selected may vary according to the modeling of the banking production process, there is almost a consensus in the literature about the basic inputs and outputs. In bank-level reviews, generally, the inputs of the production stage are labor (i.e. number of personnel, personnel expenses) and capital (i.e. fixed assets, number of branches, operational expenses) while the outputs of the profitability stage are briefly bank incomes. It is noteworthy that in some studies, non-performing loans accompany the loans as an undesirable output. However, as CAR is calculated by dividing bank capital by risk-weighted assets including non-performing loans, we prefer not to define non-performing loans as a separate variable. It is also seen that bank deposit is a quite common variable in many DEA studies related to the banking sector. At this point, one might think why bank deposit is not included in the analysis. In fact, it really makes sense to identify deposits as an intermediate variable due to its dual role in the banking production process. Unfortunately, not for the two-stage framework adopted in this study. Because defining deposits as an intermediate variable, in its most general form, requires a flow where bank resources turn into deposits and then deposits turn into investments and loans (see Fukuyama and Weber, 2010; Fukuyama and Matousek, 2011; Degl'Innocenti et al., 2017; Dia et al., 2020).

Table 1 presents the definitions of all variables. The models given in the previous section are coded in the Python programming language and solved by using the Gurobi solver.

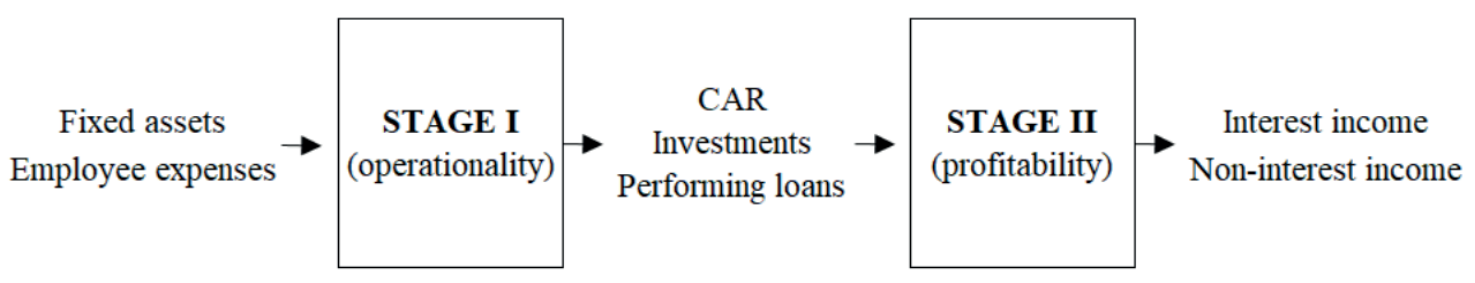

Figure 2: Two-stage Production Process for Banking Efficiency Evaluation

Table 1: Definitions of the Inputs, Intermediates and Outputs

\begin{tabular}{|c|c|}
\hline Variable Name & Definition \\
\hline \multicolumn{2}{|l|}{ Inputs } \\
\hline Fixed assets & The book value of buildings, machinery, hardware, vehicles and inventory owned by bank. \\
\hline Employee expenses & Salaries, wages, overtime, year-end bonuses, on-duty fees, personnel training fees, related fees. \\
\hline \multicolumn{2}{|l|}{ Intermediate Measures } \\
\hline CAR & The ratio of a bank's core capital to the assets and off-balanced liabilities weighted by the risk. \\
\hline Investments & $\begin{array}{l}\text { Financial asset investments including debt securities held maturity, trading securities and } \\
\text { financial derivatives. }\end{array}$ \\
\hline Performing loans & Loans that repayments are done regularly. \\
\hline \multicolumn{2}{|l|}{ Outputs } \\
\hline Interest income & Interests income from credits, banks and securities. \\
\hline Non-interest income & Fees and service charges. \\
\hline
\end{tabular}




\section{EMPIRICAL RESULTS}

Descriptive statistics for the year 2018 are given in Table 2. As can be seen, the average CAR of the commercial banks in Turkey is $16.754 \%$, which is higher than the Basel III requirement. Another notable point is that the minimum CAR in our sample is $13.08 \%$, so there is no bank with a CAR below the Basel III criteria of $10.5 \%$ for the relevant period.

Table 3 shows the stage I, stage II and overall efficiency scores. Conspicuously, only 5 of the 31 banks, i.e. about $16 \%$, are found to be efficient in both stages. These banks, which use their resources efficiently and manage their production processes better compared to other banks, are Ziraat Bank, Turkish Economy Bank, Deniz Bank, Habib Bank and Intesa Sanpaolo. Apart from these, there are 3 banks, namely Halkbank, Akbank and Yapi Kredi, which perform efficiently in operationality while there are 8 banks, namely Vakif Bank, Fibabanka, Sekerbank, Deutsche Bank, MUFG Bank Turkey, Rabobank, Garanti Bank and Societe Generale, which perform efficiently in profitability. It is noteworthy that ICBC Turkey Bank has the lowest overall efficiency score of 0.06 . This bank's low score is followed by A\&T Bank (0.08), Turkland Bank (0.08) and Citibank (0.09). The presence of the efficient units on the one hand and the units with such low efficiency scores on the other hand states that there is a significant imbalance in the Turkish banking sector from the point of financial efficiency.

The two-stage average overall efficiency score for the state-owned banks is 0.97 . Among the banks in this group, Ziraat Bank is an efficient bank and Vakif Bank is an almost efficient bank with an overall score of 0.99. Besides, it is determined that Halkbank, with an overall efficiency score of 0.92 , performs inefficiently in the stage II. That is, the bank should display a better profitability performance. After all, both the overall and divisional scores indicate that the state-owned banks in
Turkey do not experience serious problems in terms of financial efficiency.

On the other hand, the efficiency scores reveal an unpleasant picture for other types of banks. It is realized that the average overall efficiency scores of the "privately-owned banks", "foreign banks" and lastly the efficiency score of "Joint Funds Bank" are 0.51, 0.43 and 0.16 , respectively. These scores are quite low compared to the average overall efficiency score of the state-owned banks. Additionally, the average divisional efficiency scores of these banks show that a large part of their inefficiencies is due to the low efficiency scores in the stage I. Accordingly, it can be concluded that the source of inefficiency at most banks in these groups is related to the operationality. For this reason, the banks in question need to focus more on operational performance compared to profitability performance.

All the findings mentioned so far may be explained by the weight of the state-owned banks in the Turkish financial system. According to the asset sizes of the banks in 2018, the state-owned banks are in the top eight among 31 commercial banks. In fact, the state-owned banks can increase their profitability by acting more aggressively because of their trust in government support. These banks are considered as "toobig-to-fail", so to speak. Furthermore, many commercial banks other than the state-owned banks experienced financial failures in the 2001 Turkish financial crisis. For the Turkish banking system, this has led to the idea that the state-owned banks are more reliable, which in turn has increased the tendency of households and businesses to the state-owned banks.

Finally, the last row of Table 3 presents the average stage I, stage II and overall efficiency scores of all commercial banks under evaluation. The low average overall efficiency score (0.49) reveals that the Turkish banking sector faces inefficiency problem in 2018. Moreover, the average efficiency score of the stage I (0.56)

Table 2: Descriptive Statistics

\begin{tabular}{|c|c|c|c|c|c|c|c|}
\hline & \multicolumn{2}{|c|}{ Inputs } & \multicolumn{3}{|c|}{ Intermediate Measures } & \multicolumn{2}{|c|}{ Outputs } \\
\hline & $\begin{array}{c}\text { Fixed } \\
\text { assets } \\
\text { (million } € \text { ) }\end{array}$ & $\begin{array}{l}\text { Employee } \\
\text { expenses } \\
\text { (million } ¥ \text { ) }\end{array}$ & $\begin{array}{l}\text { CAR } \\
(\%)\end{array}$ & $\begin{array}{l}\text { Investments } \\
\text { (million } ¥ \text { ) }\end{array}$ & $\begin{array}{c}\text { Performing } \\
\text { loans } \\
\text { (million } € \text { ) }\end{array}$ & $\begin{array}{l}\text { Interest } \\
\text { income } \\
\text { (million } € \text { ) }\end{array}$ & $\begin{array}{c}\text { Non-interest } \\
\text { income } \\
\text { (million } € \text { ) }\end{array}$ \\
\hline Min & 0.21 & 3.29 & 13.08 & 134.55 & 62.68 & 11.45 & 0.86 \\
\hline Max & 5130.31 & 3675.52 & 190.69 & 143605.62 & 363486.75 & 53053.81 & 6624.38 \\
\hline Mean & 1075.495 & 845.418 & 16.754 & 33973.558 & 66521.077 & 11079.366 & 1343.764 \\
\hline SD & 1684.2946 & 1125.9380 & 36.8738 & 48218.8796 & 99628.2028 & 15777.7006 & 1978.6607 \\
\hline
\end{tabular}


is lower than the average efficiency score of the stage II (0.84), and the number of banks whose efficiency score in the first stage is less than the second stage is 22 . The Wilcoxon matched-pairs signed-ranks test confirms that there is a statistically significant difference between the stage I and stage II. To put it more clearly, the second stage's efficiency is higher than the first stage's efficiency in a statistical sense. These findings clarify the main source of inefficiency for the Turkish banking system and indicate that the overall inefficiency of the entire production process is predominantly based on the low efficiency scores of the first stage which is characterized as operationality. In other words, the Turkish banking sector performs better in profitability, but seems to be in trouble with the operational performance defined by employee expenses and fixed assets as the inputs. According to the statistics on the Turkish banking sector, both the number of branches and personnel decreased in 2018 compared to the previous year. This downsizing/improvement policy in the operational structure is the result of technological developments, innovative approaches and spending/saving tendencies. However, our findings show that most commercial banks in Turkey does not using their physical and/or human resources efficiently, thus the ex-post operational downsizing is not sufficient. Contrary to the downsizing/improvement policies of the sector's major players, the tendency of new players to increase their branches and employees may have a hand in the inefficient use of inputs in question (KPMG, 2019).

One can reach more striking findings by making a bank-based review from Table 3. For example, although Akbank has not grabbed the overall efficiency, it is efficient in the stage I but not in the stage II. This leads to the conclusion that if Akbank focuses on increasing its profitability, it may hit the overall efficiency score of 1. As an opposite example, Sekerbank is found efficient only in the stage II. Put another way, it is not efficient in operationality but efficient in profitability. Thus, if Sekerbank focuses on increasing its operational performance, it may be an efficient bank. The scores can be interpreted with the same logic for other banks.
Table 3: Efficiency Scores of the 31 Commercial Banks in Turkey for the Year 2018

\begin{tabular}{|c|c|c|c|}
\hline Name of bank & Stage I & Stage II & Overall \\
\hline \multicolumn{4}{|l|}{ State-owned banks } \\
\hline Ziraat Bank & 1.00 & 1.00 & 1.00 \\
\hline Halkbank & 1.00 & 0.92 & 0.92 \\
\hline Vakif Bank & 0.99 & 1.00 & 0.99 \\
\hline $\begin{array}{l}\text { Average efficiency of the state- } \\
\text { owned banks }\end{array}$ & 1.00 & 0.97 & 0.97 \\
\hline \multicolumn{4}{|l|}{ Privately-owned banks } \\
\hline Akbank & 1.00 & 0.81 & 0.81 \\
\hline Anadolubank & 0.28 & 0.57 & 0.16 \\
\hline Fibabanka & 0.18 & 1.00 & 0.18 \\
\hline Sekerbank & 0.23 & 1.00 & 0.23 \\
\hline Turkish Bank & 0.15 & 0.94 & 0.14 \\
\hline Turkish Economy Bank & 1.00 & 1.00 & 1.00 \\
\hline Isbank & 0.80 & 0.86 & 0.69 \\
\hline Yapi Kredi & 1.00 & 0.89 & 0.89 \\
\hline $\begin{array}{l}\text { Average efficiency of the privately- } \\
\text { owned banks }\end{array}$ & 0.58 & 0.88 & 0.51 \\
\hline \multicolumn{4}{|l|}{ Foreign banks } \\
\hline Alternatif Bank & 0.35 & 0.48 & 0.17 \\
\hline A\&T Bank & 0.14 & 0.56 & 0.08 \\
\hline Bank of China Turkey & 0.33 & 0.84 & 0.28 \\
\hline Burgan Bank & 0.47 & 0.56 & 0.27 \\
\hline Citibank & 0.30 & 0.31 & 0.09 \\
\hline Deniz Bank & 1.00 & 1.00 & 1.00 \\
\hline Deutsche Bank & 0.11 & 1.00 & 0.11 \\
\hline HSBC Bank & 0.55 & 0.77 & 0.42 \\
\hline ICBC Turkey Bank & 0.22 & 0.25 & 0.06 \\
\hline ING Bank & 0.54 & 0.86 & 0.46 \\
\hline MUFG Bank Turkey & 0.23 & 1.00 & 0.23 \\
\hline Odeabank & 0.82 & 0.75 & 0.61 \\
\hline QNB Finansbank & 0.55 & 0.93 & 0.52 \\
\hline Rabobank & 0.45 & 1.00 & 0.45 \\
\hline Turkland Bank & 0.08 & 0.90 & 0.08 \\
\hline Garanti Bank & 0.94 & 1.00 & 0.94 \\
\hline Habib Bank & 1.00 & 1.00 & 1.00 \\
\hline Intesa Sanpaolo & 1.00 & 1.00 & 1.00 \\
\hline Societe Generale & 0.36 & 1.00 & 0.36 \\
\hline $\begin{array}{l}\text { Average efficiency of the foreign } \\
\text { banks }\end{array}$ & 0.50 & 0.80 & 0.43 \\
\hline \multicolumn{4}{|l|}{ Bank under the deposit insurance fund } \\
\hline Joint Funds Bank & 0.19 & 0.88 & 0.16 \\
\hline Average efficiency of all banks & 0.56 & 0.84 & 0.49 \\
\hline
\end{tabular}

In addition to the efficiency scores, the frontier projections of each bank onto the efficient frontier are determined. First of all, let us clarify that the frontier projection of a DMU under evaluation consists of the target values calculated for each variable, i.e. target intermediates and target inputs/outputs. As mentioned earlier, we use an input-oriented DEA model that aims to decrease inputs while keeping outputs constant, 
so the target values are calculated for the inputs and intermediates, not for the outputs. Table 4 shows the targets of intermediate and input variables according to bank ownership structure, and Table 5 presents the distribution of overall efficiency scores by target values. Besides, since it would be more meaningful to interpret the potential increases/decreases as percentages rather than raw numbers, the percentage changes of the target values from the actual values are calculated and given in Table 6.

Considering the banks in terms of ownership structure from Table 4, it is seen that the average target CARs of the state-owned banks, privately-owned banks, foreign banks and Joint Funds Bank are 15.35\%, 16.69\%, $17.54 \%$ and $25.22 \%$, respectively. It has been a remarkable finding that this ratio increases steadily from the state-owned banks to Joint Funds Bank. The fact that the average target CAR of the state-owned banks is lower than the other bank groups is again related to their asset sizes and the idea of "too-big-to-fail". Thanks to their large scale, experience in risk management and reliance on government support, the state-owned banks can diversify their risk, so may stay at lower risk levels. The opposite of this situation is seen for other intermediate and input variables. In other words, the average target investments, performing loans, fixed assets and employee expenses of the state-owned banks are higher than the other bank groups. As Li et al. (2016) point out, this might be due to economies of scale.

Table 5 clearly shows that there is a pattern between the distribution of the efficiency scores and the target intermediates and input variables. That is to say, as the efficiency increases, the average targets of investments, performing loans, fixed assets and employee expenses also increase steadily. On the other hand, it is observed that the average target CAR decreases as the overall efficiency score increases. In such a way that higher CAR targets are associated with the banks with lower efficiency scores, while lower CAR targets are associated with the banks with higher efficiency scores. The inference is that banks found to be relatively less efficient may face higher risk and need a higher CAR target to balance risk and return, or vice versa.

Table 4: Averages of Target Values for Different Types of Banks

\begin{tabular}{|c|c|c|c|c|c|}
\hline & \multicolumn{3}{|c|}{ Intermediate Measures } & \multicolumn{2}{|l|}{ Inputs } \\
\hline & $\begin{array}{r}\text { CAR } \\
(\%)\end{array}$ & $\begin{array}{r}\text { Investments } \\
\text { (million } €)\end{array}$ & $\begin{array}{r}\text { Performing } \\
\text { loans } \\
(\text { million } €)\end{array}$ & $\begin{array}{r}\text { Fixed } \\
\text { assets } \\
\text { (million } €)\end{array}$ & $\begin{array}{r}\text { Employee } \\
\text { expenses } \\
\text { (million } ¥ \text { ) }\end{array}$ \\
\hline State-owned banks & 15.35 & 111510.26 & 267002.15 & 3495.96 & 2382.82 \\
\hline Privately-owned banks & 16.69 & 43686.56 & 93136.12 & 1254.23 & 992.52 \\
\hline Foreign banks & 17.54 & 12963.15 & 29794.14 & 319.52 & 278.69 \\
\hline Joint Funds Bank & 25.22 & 785.54 & 2413.80 & 0.74 & 4.78 \\
\hline All banks & 16.42 & 30035.76 & 68212.84 & 857.85 & 657.69 \\
\hline
\end{tabular}

Table 5: Distribution of Overall Efficiency Scores by Target Values

\begin{tabular}{|c|c|c|c|c|}
\hline \multirow[b]{2}{*}{ Variables } & \multicolumn{4}{|c|}{ Overall Efficiency Scores } \\
\hline & $\begin{array}{r}0-Q_{1} \\
0 \leq x<0.16\end{array}$ & $\begin{array}{r}Q_{1}-Q_{2} \\
0.16 \leq x<0.42\end{array}$ & $\begin{array}{r}Q_{2}-Q_{3} \\
0.42 \leq x<0.92\end{array}$ & $\begin{array}{r}Q_{3}-1 \\
0.92 \leq x \leq 1\end{array}$ \\
\hline \multicolumn{5}{|l|}{ - Intermediate Measures } \\
\hline CAR (\%) & 21.85 & 18.58 & 16.73 & 16.02 \\
\hline Investments (million $€$ ) & 1990.80 & 3447.50 & 46642.07 & 64557.07 \\
\hline Performing loans (million $€$ ) & 5672.16 & 8473.01 & 100685.31 & 150203.28 \\
\hline \multicolumn{5}{|l|}{ - Inputs } \\
\hline Fixed assets (million $€$ ) & 4.85 & 27.40 & 1406.09 & 1886.44 \\
\hline Employee expenses (million $€$ ) & 10.87 & 29.85 & 980.85 & 1528.34 \\
\hline
\end{tabular}


From Table 6, it is seen that the average potential reductions of $1.98 \%$ in CAR, $11.59 \%$ in investments, $20.24 \%$ in fixed assets and $22.21 \%$ in employee expenses have been identified for the Turkish banking sector. The only variable that indicates an increase in the sector average is performing loans with a potential increase of $2.54 \%$. Understandably, the lowest average improvement appears in CAR. This means that the actual average CAR of $16.75 \%$ (see Table 2) can be reduced to $16.42 \%$ (see Table 4 ) which is still far above the rate that both the Basel criteria suggest and the BRSA requests from the banks. These high actual as well as target CAR demonstrate that the Turkish banking sector's capital structure is strong, place the sector in a solid position within the banking sectors of emerging economies and promote the perception of trust. This finding also supports the statement of BRSA (2010) that Turkey is the only country among OECD countries that is not need public capital support in the banking sector during the 2008 global crisis. In this positive atmosphere on the bank's capital adequacy, the effect of the measures taken in 2018 to protect the financial structures of intermediary institutions is significant. However, the cautious behavior of some banks after the 2008 global financial crisis also plays a role in this situation.

Another finding of our analysis is that there is no bank with a target CAR below $10.5 \%$. Hence, it can be concluded that the regulated CAR set by Basel III is not high to guide the commercial banks in Turkey to the efficient frontier. That is, the Basel III regulation does not constitute an impediment for the Turkish banking system. Nevertheless, although $1.98 \%$ reduction on average is interpreted as the Turkish banking sector stands very close to the average target CAR, it should be noted that there are higher differences between the real and target values in group-based and bank-based review. As an example, while the average CAR of the foreign banks should be decreased by $7.01 \%$, the potential CAR extension/reduction of some banks in this group reaches approximately $90 \%$. By the way, the maximum potential CAR extension belongs to Turkland Bank with $87.18 \%$ and the maximum potential CAR reduction belongs to Bank of China Turkey with $85.91 \%$. Moreover, the 18 banks' actual CAR are higher (banks with negative percentage changes) and the 9 banks' actual CAR are lower (banks with positive percentage change) than their targets. More clearly, almost $58 \%$ of the banks has to decrease and almost $29 \%$ of the banks has to increase their CAR to catch the target. By applying the target CAR value, banks are expected to achieve a risk-return balance. A bank can hit its potential improvement target by making adjustments to whichever part of the CAR it wishes to change. For example, in accordance with the working principles of banking sector, if a bank needs to increase its CAR, it would be more reasonable to decrease its risk-weighted assets instead of increasing the capital due to the cost of equity.

Here, it is important to draw attention to a point: for inefficient DMUs to be efficient, they need to capture not only the CAR targets, but also the improvement targets of other intermediate and input variables given in Table 6. That is to say, in order to be a relatively efficient bank, for example, Yapi Kredi should increase its CAR and performing loans by $4.86 \%$ and $1.88 \%$, while decrease its investments, fixed assets and employee expenses by $16.61 \%, 10.83 \%$ and $20.03 \%$, respectively. Again, the same comments can be obtained for other inefficient banks as well. On the other hand, the highest potential reductions for the sector appear in the fixed assets and employee expenses by $20.24 \%$ and $22.21 \%$. While the potential reductions of the state-owned banks for the fixed assets and employee expenses are $2.54 \%$ and $3.73 \%$, these rates reach $30.89 \%$ and $33.56 \%$ when it comes to the foreign banks. The fact that the average operational efficiency score of the state-owned banks is higher than the other bank groups supports these findings and indicates that the state-owned banks use their initial sources more efficiently. 
Table 6: Improvement Targets (\%)

\begin{tabular}{|c|c|c|c|c|c|}
\hline Name of bank & CAR & Investments & Performing loans & Fixed assets & Employee expenses \\
\hline \multicolumn{6}{|l|}{ State-owned banks } \\
\hline Ziraat Bank & 0.00 & 0.00 & 0.00 & 0.00 & 0.00 \\
\hline Halkbank & 13.97 & -14.26 & -5.16 & -7.95 & -7.95 \\
\hline Vakif Bank & -5.64 & 1.13 & -1.34 & -0.88 & -3.95 \\
\hline Average & 2.25 & -4.42 & -1.87 & -2.54 & -3.73 \\
\hline \multicolumn{6}{|l|}{ Privately-owned banks } \\
\hline Akbank & -8.05 & -25.62 & 11.09 & -21.64 & -18.78 \\
\hline Anadolubank & -2.65 & 56.87 & 29.19 & -85.17 & -84.35 \\
\hline Fibabanka & -10.79 & -3.64 & -7.67 & -84.44 & -81.63 \\
\hline Sekerbank & 5.63 & -0.20 & 0.07 & -77.10 & -76.62 \\
\hline Turkish Bank & 44.53 & -13.79 & 22.80 & -95.03 & -85.93 \\
\hline Turkish Ekonomy Bank & 0.00 & 0.00 & 0.00 & 0.00 & 0.00 \\
\hline Isbank & -0.26 & -8.22 & -4.34 & -31.44 & -31.44 \\
\hline Yapi Kredi & 4.86 & -16.61 & 1.88 & -10.83 & -20.03 \\
\hline Average & -1.19 & -14.64 & 1.97 & -27.00 & -26.37 \\
\hline \multicolumn{6}{|l|}{ Foreign banks } \\
\hline Alternatif Bank & 6.12 & -33.21 & -27.41 & -93.34 & -83.26 \\
\hline A\&T Bank & 40.67 & -75.81 & 52.80 & -99.40 & -92.19 \\
\hline Bank of China Turkey & -85.91 & -56.05 & 264.58 & -84.26 & -72.33 \\
\hline Burgan Bank & -11.41 & 6.40 & -15.27 & -73.26 & -73.26 \\
\hline Citibank & -6.08 & -51.87 & 123.60 & -90.73 & -90.73 \\
\hline Deniz Bank & 0.00 & 0.00 & 0.00 & 0.00 & 0.00 \\
\hline Deutsche Bank & -22.29 & -5.21 & 256.10 & -88.91 & -88.91 \\
\hline HSBC Bank & -14.75 & -52.29 & 6.03 & -57.99 & -57.99 \\
\hline ICBC Turkey Bank & -24.44 & -69.29 & 1.76 & -99.29 & -94.34 \\
\hline ING Bank & -25.62 & -17.34 & -1.49 & -53.63 & -53.63 \\
\hline MUFG Bank Turkey & 71.22 & -70.27 & -37.28 & -76.82 & -76.82 \\
\hline Odeabank & -18.47 & -38.00 & -6.46 & -38.68 & -38.68 \\
\hline QNB Finansbank & 10.73 & -25.72 & 5.49 & -54.26 & -48.37 \\
\hline Rabobank & -53.08 & 403.47 & 336.18 & -55.20 & -55.20 \\
\hline Turkland Bank & 87.18 & -18.79 & 632.96 & -95.05 & -92.49 \\
\hline Garanti Bank & -9.50 & 0.00 & 18.63 & -5.69 & -18.15 \\
\hline Habib Bank & 0.00 & 0.00 & 0.00 & 0.00 & 0.00 \\
\hline Intesa Sanpaolo & -16.65 & 0.00 & -30.94 & 0.00 & 0.00 \\
\hline Societe Generale & -24.93 & 166.30 & 1198.06 & -63.76 & -63.76 \\
\hline Average & -7.01 & -15.72 & 10.21 & -30.89 & -33.56 \\
\hline \multicolumn{6}{|c|}{ Bank under the deposit insurance fund } \\
\hline Joint Funds Bank & -75.89 & -47.10 & 59.62 & -98.54 & -83.69 \\
\hline Average $^{4}$ & -1.98 & -11.59 & 2.54 & -20.24 & -22.21 \\
\hline
\end{tabular}

\footnotetext{
${ }^{4}$ All averages in Table 6 are calculated using the raw numbers of targets obtained, not on percentages.
} 


\section{CONCLUSION}

Turkey suffered from a currency crisis in 2018. The unfavorable global and domestic developments experienced in 2018 created a notable risk impact on the Turkish banking sector and slowed down the economic activity. The success or failure of banks in risk management during the period of currency crisis constitutes the research question of this study. Because the banking sector is not only the first sector to react to domestic financial developments, but also the first sector to recover when conditions are improved. In other words, the banking sector's reactions are the leading indicators for other actors of economy (KPMG, 2019). Moreover, banks constitute a large part of the Turkish financial sector. Therefore, banks should strengthen their asset quality as well as capital structure and need to work effectively in order to maintain the robustness of the financial system and to support the economic growth of Turkey. With a good balance of risk and return, banks can operate efficiently. In this respect, it is very important to manage capital adequacy ratio (CAR), which is a basic indicator in controlling the financial risk. If CAR is higher than it should be, there may be a case of giving up the return. If CAR is lower than it should be, there may be an excessive risk loading. Since the issue is so critical, the Basel Committee put forward a set of minimum capital adequacy regulations for purposes such as keeping banks working at common standards and protecting them against the risk factors. Although the Basel criteria help banks to cope with risk, these regulations should be evaluated together with each economy's and even bank's own dynamics. Thus, determining a CAR that has a good risk-return balance is vital. By focusing on the link between efficiency, risk and return, this study aims to present: (i) a two-stage efficiency evaluation of the commercial banks in Turkey in 2018; (ii) to provide target values in terms of key indicators to operate efficiently; and (iii) to make a deeper examination in the projection of capital adequacy. A relational two-stage DEA model is employed with the variable returns to scale assumption. Since the black-box on banking efficiency is desired to be analyzed, the study is conducted on two relational stages, namely operationality and profitability.

According to the empirical findings, only $16 \%$ of the banks is found to be relatively efficient in both stages. The gap between the efficiency scores reveals the fact that there is a significant performance imbalance in the Turkish banking sector at the commercial bank level. Among all bank groups classified according to the ownership structure, it is determined that the state-owned banks have the highest average score in both the first and second stage efficiency. The sectoral average efficiency score, on the other hand, is found to be 0.42 , indicating that the Turkish banking sector faces an inefficiency problem in 2018. Most importantly, it is identified that the first stage efficiency is statistically lower than the second stage efficiency, and therefore the inefficiency problem in the Turkish banking sector particularly stems from the operational performance. At this point, it can be recommended to use physical and human resources efficiently to increase the operationality. In addition to this, some measures such as developing in rural areas, adapting to small-scale branch banking, increasing sales, keeping up with technological developments, employing new banking concepts and reaching customers through channels other than face-to-face interaction - i.e. fintech services, internet and mobile banking - can be advised for banks with low operational performance. In fact, it is necessary to invest in digital transformation instead of more fixtures and human resources in the Turkish banking sector. Tailoring products and services to customers will allow more savings to be included in the economy and further investment to be realized. Thanks to the increased operational efficiency, banks are likely to make a progress in terms of profitability as well.

In terms of target values, it is observed that the state-owned banks have the lowest average target CAR as well as the highest average target investments, performing loans, fixed assets and employee expenses compared to other bank groups. These findings can be attributed to the many factors specific to the state-owned-banks, i.e. having larger asset sizes, trusting in government supports, being too-big-to-fail, appearing as a safe port after the financial crises/during the periods of high vulnerability, channeling the risk to many sources, and finally the issues associated with economies of scale. Apart from these, a pattern is reached in which "high efficiency scores overlap low CAR targets" and "low efficiency scores overlap high CAR targets". Furthermore, it is determined that the target CARs of all banks are above the Basel III requirement of 10.5\% and the Turkish Banking Regulation and Supervision Agency's requirement of $12 \%$. Thus it is concluded that the Basel III regulation does not constitute an obstacle for the Turkish banking sector's adjustments in the way of reaching efficient frontier. Nevertheless, approximately $58 \%$ of the commercial banks should decrease and almost $29 \%$ of the banks should rise their CAR to hit the calculated target. Finally, the variable of employee 
expenses is identified to have the maximum potential reduction among other variables.

Turkey is generally described as a fragile economy. For this reason, it is essential to provide empirical findings regarding the banking sector's efficiency especially for a period when sudden changes have been experienced in the economic indicators. Besides, setting targets for CAR in the mentioned financial ecosystem is considered as a substantial contribution to the literature. However, evaluating the efficiency of banks in a cross-sectional manner is the limitation of this study. Performing a multi-period two-stage efficiency analysis is recommended for future research. By establishing a link between the time points, not only the variations in the efficiency scores and targets, but also the bottlenecks of the banking production process can be monitored over a period of time. 


\section{REFERENCES}

Abreu, M., and Mendes, V. (2002). Commercial bank interest margins and profitability: Evidence from E.U. countries. University of Porto Working Paper Series, 122.

BRSA. (2010). Sorularla Basel III. Retrieved from https:// www.bddk.org.tr/ContentBddk/dokuman/duyuru_basel_0001_53.pdf

BRSA. (2018). 2018 annual report. Retrieved from https://www. bddk.org.tr/ContentBddk/dokuman/hakkinda_0013_06. pdf

BRSA. (2019). Turkish banking sector main indicators June 2019. Retrieved from https://www.bddk.org.tr/ContentBddk/dokuman/veri_0023_08.pdf

Berger, A. N. (1995). The profit-structure relationship in banking--tests of market-power and efficient-structure hypotheses. Journal of Money Credit and Banking, 27(2), 404-431.

Besanko, D., and Kanatas, G. (1996) The regulation of bank capital: Do capital standards promote bank safety?. Journal of Financial Intermediation, 5(2), 160-183.

Bhattacharya, H. (2013). Capital regulation and rising risk of banking industry: A financial accounting perspective. Academy of Banking Studies Journal, 12(1), 31-59.

Bhattacharyya, A., Lovell, C. A. K., and Sahay, P. (1997). The impact of liberalization on the productive efficiency of Indian commercial banks. European Journal of Operational Research, 98(2), 332-345.

Bialas, M., and Solek, A. (2010). Evolution of capital adequacy ratio. Economics \& Sociology, 3(2), 48-57.

Bouheni, F. B., and Rachdi, H. (2015). Bank capital adequacy requirements and risk-taking behavior in Tunisia: $A$ simultaneous equations framework. Journal of Applied Business Research, 31(1), 231-238.

Buyuksalvarci, A., and Abdioglu, H. (2011). Determinants of capital adequacy ratio in Turkish Banks: A panel data analysis. African Journal of Business Management, 5(27), 11199-11209.

Cai, M., and Huang, Z. (2014). Analysis of non performing loan and capital adequacy ratio among Chinese banks in the post-reform period in China. Journal of Advanced Studies in Finance, 5(2), 133-144.

Cecchetti, S. G., and Li, L. (2008). Do capital adequacy requirements matter for monetary policy?. Economic Inquiry, 46(4), 643-659.

Chen, Y., Cook, W. D., Li, N., and Zhu, J. (2009). Additive efficiency decomposition in two-stage DEA. European Journal of Operational Research, 196(3), 1170-1176.

Chen, Y., Cook, W. D., and Zhu, J. (2010). Deriving the DEA frontier for two-stage processes. European Journal of Operational Research, 202(1), 138-142.

Dagher, J., Dell'Ariccia, G., Laeven, L., Ratnovski, L., and Tong, H. (2016). Benefits and costs of bank capital. IMF Staff Discussion Note, 16/04. Retrieved from https://www.imf.org/ external/pubs/ft/sdn/2016/sdn1604.pdf
Degl'Innocenti, M., Kourtzidis, S. A., Sevic, Z., and Tzeremes, N. G. (2017). Investigating bank efficiency in transition economies: A window-based weight assurance region approach. Economic Modelling, 67, 23-33.

Dia, M., Golmohammadi, A., and Takouda, P. M. (2020). Relative efficiency of Canadian banks: A three-stage network bootstrap DEA. Journal of Risk and Financial Management, 13(4), 68.

Fukuyama, H., and Matousek, R. (2011). Efficiency of Turkish banking: Two-stage network system. Variable returns to scale model. Journal of International Financial Markets, Institutions and Money, 21(1), 75-91.

Fukuyama, H., and Weber, W. L. (2010). A Slacks-based inefficiency measure for a two-stage system with bad outputs. Omega, 38(5), 398-409.

Grigorian, D. A., and Manole, V. (2006). Determinants of commercial bank performance in transition: An application of data envelopment analysis. Comparative Economic Studies, 48(3), 497-522.

Gual, J. (2011). Capital requirements under Basel III and their impact on the banking industry. Barcelona: La Caixa.

Ho, C. T. B., and Oh, K. B. (2008). Measuring online stockbroking performance. Industrial Management \& Data Systems, 108(7), 988-1004.

Jackson, P. M., and Fethi, M. D. (2000). Evaluating the efficiency of Turkish commercial banks: An application of DEA and Tobit Analysis. In proceedings of the International DEA Symposium, University of Queensland, Brisbane.

Kao, C. (2009). Efficiency decomposition in network data envelopment analysis: A relational model. European Journal of Operational Research, 192(3), 949-962.

Kao, C., and Hwang, S. N. (2008). Efficiency decomposition in two-stage data envelopment analysis: An application to non-life insurance companies in Taiwan. European Journal of Operational Research, 185(1), 418-429.

Kao, C., and Hwang, S. N. (2011). Decomposition of technical and scale efficiencies in two-stage production systems. European Journal of Operational Research, 211(3), 515-519.

Karray, S. C., and Chichti, J. E. (2013). Bank size and efficiency in developing countries: Intermediation approach versus value added approach and impact of non-traditional activities. Asian Economic and Financial Review, 3(5), 593-613.

KPMG. (2019). Bankacılık Sektörel Bakış. Retrieved from https:// assets.kpmg/content/dam/kpmg/tr/pdf/2019/01/sektorel-bakis-2019-bankacilik.pdf

Li, Y., Chen, Y. K., Chien, F. S., Lee, W. C., and Hsu, Y. C. (2016). Study of optimal capital adequacy ratios. Journal of Productivity Analysis, 45(3), 261-274.

Liang, L., Cook, W. D., and Zhu, J. (2008). DEA models for twostage processes: Game approach and efficiency decomposition. Naval Research Logistics, 55(7), 643-653. 
Lim, S., and Zhu, J. (2016). A note on two-stage network DEA model: Frontier projection and duality. European Journal of Operational Research, 248(1), 342-346.

Lim, S., and Zhu, J. (2019). Primal-dual correspondence and frontier projections in two-stage network DEA models. Omega, 83, 236-248.

Modigliani, F., and Miller M. H. (1963). Corporate income taxes and the cost of capital: A correction. The American Economic Review, 53(3), 433-443.

Mushtaq, M., Ismail, A., and Hanif, R. (2015). Credit risk, capital adequacy and bank's performance: An empirical evidence from Pakistan. International Journal of Financial Management, 5(1), 27-32.

Nigmonov, A. (2010). Bank performance and efficiency in Uzbekistan. Eurasian Journal of Business and Economics, 3(5), 1-25.

Polat, A., and Al-khalaf, H. (2014). What determines capital adequacy in the banking system of Kingdom of Saudi Arabia? A panel data analysis on Tadawul banks. Journal of Applied Finance \& Banking, 4(5), 27-43.

Posner, E. A. (2015). How do bank regulators determine capital-adequacy requirements?. The University of Chicago Law Review, 82(4), 1853-1895.

Reynolds, S. E., Ratanakomut, S., and Gander, J. (2000). Bank financial structure in pre-crisis East and Southeast Asia. Journal of Asian Economics, 11(3), 319-331.

Seiford, L. M., and Zhu, J. (1999). Profitability and marketability of the top 55 US commercial banks. Management Science, 45(9), 1270-1288.
Sexton, T. R., and Lewis, H. F. (2003). Two-stage DEA: An application to major league baseball. Journal of Productivity Analysis, 19(2-3), 227-249.

Sturm, J. E., and Williams, B. (2008). Characteristics determining the efficiency of foreign banks in Australia. Journal of Banking \& Finance, 32(11), 2346-2360.

Tabari, N. A. Y., Ahmadi, M., and Emami, M. (2013). The effect of liquidity risk on the performance of commercial banks. International Research Journal of Applied and Basic Sciences, 4(6), 1624-1631.

The Banks Association of Turkey. (2019). Banks in Turkey 2018. Retrieved from https://www.tbb.org.tr/en/Content/Upload/Dokuman/161/Banks_in_Turkey_2018.pdf

Wang, C. H., Gopal, R. D., and Zionts, S. (1997). Use of data envelopment analysis in assessing information technology impact on firm performance. Annals of Operations Research, 73, 191-213.

Wang, K., Huang, W., Wu, J., and Liu, Y. N. (2014). Efficiency measures of the Chinese commercial banking system using an additive two-stage DEA. Omega, 44, 5-20.

Wanke, P., and Barros, C. (2014). Two-stage DEA: An application to major Brazilian banks. Expert Systems with Applications, 41(5), 2337-2344.

Williams, H. T. (2011). Determinants of capital adequacy in the banking sub-sector of the Nigeria economy: Efficacy of Camels. (A model specification with co-integration analysis). International Journal of Academic Research in Business and Social Sciences, 1(3), 233-248.

Zhu, J. (2000). Multi-factor performance measure model with an application to Fortune 500 companies. European Journal of Operational Research, 123(1), 105-124. 